\title{
POLITENESS STRATEGIES APPLIED IN THE DIRECTIVE SPEECH ACT IN THE DA VINCI CODE AND ITS TRANSLATION
}

By:

\section{Sumardiono}

\begin{abstract}
This research aims at identifying what and how politeness strategies are applied in the directive speech act in The Da Vinci Code and how they are transfered into their translation. There are twenty four data gained from chapter one to chapter twenty of the novel. First, the researcher identify the directive speech act in The Da Vinci Code, the utterances then classified based on the politeness strategy applied in the context. In the analysis the utterances are described based on the situational context. The analysis also explain why the speaker apply the strategy. The strategy used in the source text is then compared with that in the source text. There are some conclussions derived; only three strategies propossed by Brown and Levinson were apllied in the directive speech act. They are bald on record, positive politenss and negative politeness. There is no off record strategy applied in the data. The same communicant (the speakers and hearers) applied different strategies in different situation, meaning that there is no single strategy applied to similar interlocutors at anytime.All the strategies applied in the source text are transferred exactly into the same strategies in the target text. There is no strategy shift found.
\end{abstract}

\section{Key words:}

\section{INTRODUCTION}

Eventhough translation is simply transferring messages from source text into the target one, the process of getting the messages is not a trivial thing. Translation is rendering the meaning of a text into another language in a way that the author intended the text (Newmark,1995:5). The way a language packages its messages differs from one another. Meaning components are packaged into lexical items, but they are packaged differently in one language than in another (Larson, 1984:6). It is why transferring messages is not as simple as merely transforming the form of the chunk of the languange. Translation, therefore, involves two different languages not only in form and system, which is surface structure, but also in its deep structure. Translation is basically a change in form (Larson, 1984:2)

By definition, translation is a process of transferring messages from a code to another. Therefore, the process needs two codes at the same time. Consequently, its main role is bridging two different systems both grammatically in linguistic domain and culturally in non linguistic domain. These two different codes are bridged by deep structure manifested by their surface structure. 
As an applied linguistics, translation needs other disciplins to work with messages. In the process of transferring messages, some apparatus to identify meanings, are needed. They cover linguistics which explains the process in the level of morphology, syntax and discourse. Linguistics is a discipline which bridges to understand the messages behind both the source text and the target one.

This research tries to identify what and how politeness strategies applied applied in the directive speech act in The Da Vinci Code and how they are transfered into their translation. Directive speech act is considered as a speech act which has the most possibilities of doing face threatenning act. It is why an analysis on how the application of politeness strategy in directive speech act and how it is transfered into its translation is considered to be significantly applicable.

\section{Translation and Pragmatics}

During translation process, textual understanding of a text is simply not sufficient. It is because meaning is not merely behind words, phrases and clause independently. It is both behind the superficial items and the context where words, phrases and clauses appear to convey messages. Simply transfering word for word in translation process is both meaningless and illogical. There is no one-to-one correspondence between orthographic words and element of meaning within or across languages (Baker, 1992:11).

Text can only be approached through interpretation (Farwell dan Heimrich, 2007:12). It is context which is taken into account to understand the message behind the text. To interpret how an utterance means for the interlocutor, context is needed. Context is also needed to make utterance free from ambiguity. Without it, an utterance may come ambiguous. Context comprises situational and cultural. Situational context is who speaks to whom, where and in what condition an utterance appears. Knowing the appropriate meaning of a non linguistic event also depends on the context of who does what, when, where and for what reasons (Nida,2001:14 ) A single utterance may convey different meaning in different situation and cultural background. The same utterance can have opposite interpretations, depending on the context in which it is processed (Hickey, 1998:49). Moreover, in the term of communication Hatim \& Mason (1990) state that translation is communicative process in a certain social context.

The understanding of both source language and target language cultural background is essential for a translator. Cultural context comprises all the values, belief system and also the history that shape a society. Language constitutes the most distinctive feature of a culture, 
which may be described in a simplistic manner as the totality of the believe and practices of the societies (Nida, 2001:13)

Consequently, the role of pragmatics in the discussion of translation plays an essential part. It may be fatal not to involve pragmatics into account in the discussion of translation studies. Pragmatics makes it possible for a translator to get the meaning not supperficially but deep into the ilocutionary message. Moreover, in the pragmatics approach, a text does not by itself convey a meaning, it is a result of a text and its context. A text simply appears based on the intention of the speaker to respond to something outside.

\section{Politeness in Conversation}

In order to keep a good relationship in interaction, interactants apply certain behaviour. The norm of this behaviour is known as politeness. Politeness in interaction, can be defined as the means employed to show awareness of other's face (Yule,1996:60). While Brown and Levinson (1987) state that Politeness is defined as the strategies employed by the speaker to achieve a variety of goals, such as promoting or maintaining harmonious relationship. Thus, politeness is applied in conversation to achieve a harmonious relationship among the interactants.

In relation to politeness, there is a term closely related to this concept; face. Yule (1996) states that face is the public self image of a person. He, furthermore, says that face refers to emotional and social sense of self that everyone has and expects everyone else to recognize. Meanwhile, Brown and Levinson (1987) define face as something that is emotionally invested, and that can be lost, maintained or enhanced, and must be constanly attended to in interaction. In a conversation, interactants try to maintain two types of face They are negative face and positive face. Positive face is defined as the positive and consistent image people have for themselves, and desire for approval (Brown and Levinson: 61). On the other hand, 'negative face' is "the basic claim to territories, personal preserves, and rights to non-distraction"(Brown and Levinson, 1987: 61).

Positive politeness is conducted by fulfilling positive face in two ways, 1) by expressing similarities among or 2) by appreciating the interactant's self image. Meanwhile, negative politeness 1) saving the interactant's face (either negative face or positive face) or avoiding FTA (face threatening acts)and 2) by giving respect to the adressee not being imposed on. In other way, we can say that politeness can be achieved by mitigating FTA and promote FSA. 
In order to meet the politeness, there are four politeness strategies proposed by Brown and Levinson (1987).

\section{Bald on record}

Speaker mostly uses bold on record when he wants to do FTA with maximum efficiency toward the hearer face (Brown and Levinson, 1987:95). Of course the speaker has to take social distance, imposition and power into account when using this strategy. Close friends and family, for example, are the right people who use it. This strategy privides no effort to reduce the impact of FTA. This is also used effectively in an emergency situation. Here are the examples:

Put your shoes out side! (among family)

Give me the book! (among close friends)

Help! (emergency situation)

\section{Positive politeness}

Positive politeness is redress directed to the addresee's positive face (Brown and Levinson, 1987:101). In this strategy, the speaker tries to keep the hearer's positive face. As Yule (1996) states that positive face is the need to be accepted, even liked, by others, to be treated as a member of the same group and to know the his or her wants are shared by others. Therefore, in this strategy, the speaker involves the hearer as a group member and share similar interest and likes. The speaker tries to reduce the distance between him and the hearer by expressing friendliness and similar interest and minimize the FTA. Here are the examples "You have been studying long, you must be tired. How about taking some break?" "Oh, long time no see. How about tonight in our favourite restaurant?"

\section{Negative politeness}

Negative politeness is redressive action addressed to the addresee's negative face (Brown and Levinson, 1987:101). Further, he said that it performs the function of minimazing the particular imposition that the FTA unavoidably effects. By applying this strategy, a speaker is making a social distance. The reasons of applying this strategy are assuming that the speakers may be imposing and intruding on the hearer 's space. The example of this strategy:

“Could you lend me a pen?." (intended to borrow a pen)

"I am sorry to disturb you, but can you open door?"

\section{Off record}

This strategy is applied by just giving hints to the hearer. The speaker, actually wants to do an FTA but he does wants to avoid the responsibility of doing it (Brown and Levinson, 
1987:211). If then the hearer gets the messages hinted by the speaker, it means that the speaker manages to communicate more that what it is said. Off record strategy gives the hearer an apportunity not to respond just what the speaker intended. Here are the examples: "I forget to bring the pen with me." (intended to borrow a pen)

\section{METHOD}

In this study the researcher indentified not only what politeness strategies are applied in the directive speech act in The Da Vinci Code but also how they are applied. Because this research is a translation research, it also describes how those strategies are transfered into the translation/target language. The researcher found twenty four data from chapter one to chapter twenty in the novel. First, the directive speech acts in The Da Vinci Code are identified. The utterances are then classified based on the politeness strategy and situational context. It is also explained why the speaker applies the strategy. At the end of the analysis the researcher compared the strategies used in the source text to those applied in the target text.

\section{III.FINDING AND DISCUSSION}

\section{General Description of the Data}

Based on the categories of the part of speech, there are twenty four utterances with directive speech act found in the first twenty chapter of the novel. The utterances then are categorized based on the politenes strategy which then come to the following table

\begin{tabular}{|c|l|c|}
\hline No & \multicolumn{1}{|c|}{ Politeness Strategy } & Number of items \\
\hline 1 & Bald on record & 9 \\
\hline 2 & Positive Politness & 8 \\
\hline 3 & Negative Politeness & 4 \\
\hline 4 & Off Record & 0 \\
\hline
\end{tabular}

It was found out that bald on record is the most politeness strategy applied in the directive speech act in The Da Vinci Code. It is so for the relation between interctants in the conversation are mostly at the same social status. The main characters in the novel are Sophie and Langdon. They, eventhough just met each other, are both expert in their own field which indicates no social distance between them. Meanwhile, positive politeness is the second most politeness strategy applied in the utterances. This strategy is applied in a conversation between those who are already know one another which therefore indicates in group solidarity. 
The third strtegy applied in the conversation is negative politeness. This strategy is applied mostly between two people who do not know each other very well which therefore indicates social distance and negative face which should be addressed. The last strategy, off record is not found. However, The same interactants (the speakers and hearers) applied different strategies in different situation, meaning that there is no one singgle strategy applied to similar interactant at all time. The table below decribes the distribution of the directive speech act and the politeness strategy.

\begin{tabular}{|c|c|c|c|c|}
\hline No & Source Text & PS & Target Text & PS \\
\hline 1 & $\begin{array}{l}\text { If you would be so kind... could } \\
\text { you take the man's name and } \\
\text { number and tell him I'll try to call } \\
\text { him before I leave Paris on } \\
\text { Tuesday? Thank you. }\end{array}$ & 3 & $\begin{array}{l}\text { Tolonglah Tuan yang baik...tanyakan nama orang } \\
\text { tersebut dan nomer teleponnya, dan katakan juga saya } \\
\text { akan menghubunginya sebelum saya meninggalkan } \\
\text { Paris hari Selasa. Terima kasih. }\end{array}$ & 3 \\
\hline 2 & Speak & 1 & Bicaralah & 1 \\
\hline 3 & $\begin{array}{l}\text { So, my pupil, tell me what I must } \\
\text { know. }\end{array}$ & 2 & Jadi, muridku, ceritakan apa yang harus kutahu & 2 \\
\hline 4 & $\begin{array}{l}\text { You must retrieve the stone for } \\
\text { me. Immediatly. Tonight. You } \\
\text { understand the stake. }\end{array}$ & 1 & $\begin{array}{l}\text { Kau harus menemukan batu kunci itu untukku, segera, } \\
\text { malam ini. Kau tahu resikonya }\end{array}$ & 1 \\
\hline 5 & $\begin{array}{l}\text { Mr. Langdon, can you at least } \\
\text { guess what our victim might have } \\
\text { wanted to discuss on the night he } \\
\text { was killed? It might be helpful. }\end{array}$ & 2,3 & $\begin{array}{l}\text { Mr. Langdon, dapatkah Anda, setidaknya menerka, apa } \\
\text { yang kira-kira ingin didiskuasikan oleh korban dengan } \\
\text { Anda pada malam dia terbunuh? Itu mungkin akan } \\
\text { sangat membantu. }\end{array}$ & 2,3 \\
\hline 6 & This way & & Ke sini & \\
\hline 7 & Please slide under. & 3 & Silakan menyelinap ke bawah & 3 \\
\hline 8 & Of course. Tell me what to do. & 1 & Tentu saja. Katakan apa yang harus kulakukan. & 1 \\
\hline 9 & Go on. & 1 & Teruskan & 1 \\
\hline 10 & Look at his left hand. & 1 & Lihat tangan kirinya. & 1 \\
\hline 11 & $\begin{array}{l}\text { This line is secure Mr. Langdon. } \\
\text { You may use it. }\end{array}$ & 3 & Ini aman, Mr. Langdon. pakailah. & 2 \\
\hline 12 & It's time for breakfast. & 4 & Waktunya makan pagi. & 4 \\
\hline 13 & $\begin{array}{l}\text { For my plan to succeed, you must } \\
\text { allow Silas to answer only to me } \\
\text { for several days. }\end{array}$ & 1 & $\begin{array}{l}\text { Untuk menjalankan rencanaku, kau harus membiarkan } \\
\text { Silas hanya berbicara padaku untuk beberapa hari saja. }\end{array}$ & 1 \\
\hline 14 & The two of you will not speak. & 3 & Kalian berdua tidak akan saling bicara. & \\
\hline 15 & You will treat him with respect? & 3 & Anda akan memperlakukannya dengan hormat & \\
\hline 16 & $\begin{array}{l}\text { The rest room. Of course. Let's } \\
\text { take a break for a few minutes. }\end{array}$ & 2 & $\begin{array}{l}\text { Kamar kecil. Tentu saja. Mari kita istirahat beberapa } \\
\text { menit. }\end{array}$ & 2 \\
\hline
\end{tabular}




\begin{tabular}{|c|c|c|c|c|}
\hline 17 & $\begin{array}{l}\text { Please come find me directly,Mr. } \\
\text { Langdon. There is more we need } \\
\text { to discuss. }\end{array}$ & 2 & $\begin{array}{l}\text { Harap Anda langsung menyusul kesana. Ada yang } \\
\text { masih harus kita diskusikan. }\end{array}$ & 2 \\
\hline 18 & $\begin{array}{l}\text { I've got a phone call to make. Be } \\
\text { damned sure the rest room is the } \\
\text { only place Langdon goes. }\end{array}$ & 1 & $\begin{array}{l}\text { Aku harus menelpon. Pastikan Langdon hanya ke } \\
\text { kamar kecil. }\end{array}$ & 1 \\
\hline 19 & $\begin{array}{l}\text { Look in your jacket left pocket. } \\
\text { You'll find proof they are } \\
\text { watching you. }\end{array}$ & 2 & $\begin{array}{l}\text { Periksa saku kiri jas Anda. Anda akan mendapatkan } \\
\text { bukti jika Anda sedang diawasi. }\end{array}$ & 2 \\
\hline 20 & No. & 1 & Jangan & 1 \\
\hline 21 & $\begin{array}{l}\text { Leave it in your pocket. If you } \\
\text { throw it out, the signal will stop } \\
\text { moving, and they'll know you } \\
\text { foud the dot. }\end{array}$ & 1 & $\begin{array}{l}\text { Biarkan itu di dalam saku Anda. Jika Anda } \\
\text { membuangya, mereka tahu Anda telah menemukan alat } \\
\text { itu. }\end{array}$ & 1 \\
\hline 22 & I think you better take this call. & 3 & Saya rasa lebih baik Anda menerima telepon ini & 3 \\
\hline 23 & Sophie, please listen. & 2 & Sophie, kumohon dengarkan & 2 \\
\hline 24 & $\begin{array}{l}\text {... would you mind if I take } \\
\text { sometime alone to pray before I } \\
\text { look around. }\end{array}$ & 3 & $\begin{array}{l}\text {... Kau tidak keberatan jika aku ingin sendirian untuk } \\
\text { berdoa sebelum melihat-lihat? }\end{array}$ & 3 \\
\hline
\end{tabular}

\section{How Politeness Stretegy is Applied and How it is Transferred into The Target Text}

\section{Bald on Record}

Nine utterances applying bald on record were found. The social distance of the interactants are mostly close or the speaker has power toward the hearer. Here is one of the examples:

\begin{tabular}{|c|l|l|}
\hline No & \multicolumn{1}{|c|}{ Source Text } & \multicolumn{1}{c|}{ Target Text } \\
\hline 2 & Speak & Bicaralah \\
\hline
\end{tabular}

This is a conversation between Aringarosa, a bishop, and Silas, a faithful follower of Opus Dei who calls Aringarosa as "Teacher". Silas was saved by Aringarosa from a street. This gives power to Aringarosa in this communication. The speaker, Aringarosa, applies bald on record strategy in order to maximize effeciency toward the hearer's face. Brown and Levinson (1987) state that speaker mostly use bold on record when he wants to do FTA with maximum efficiency toward the hearer's face. Bald on record is signed by the use of imperative sentence as it is stated by Aringarosa, "Speak."

In the translation the utterance is in the same form. "Speak." is translated into, "Bicaralah" which is also imperative and belongs to bald on record as Brown and Levinson 
(1987) state that direct imperative stands out as clear example of bald on record usage. So there is no shift of politeness strategy in the translation.

Other example of bald on record strategy applied in utterance is one uttered by Sophie:

\begin{tabular}{|c|l|l|}
\hline No & \multicolumn{1}{|c|}{ Source Text } & \multicolumn{1}{|c|}{ Target Text } \\
\hline 19 & $\begin{array}{l}\text { Leave it in your pocket. If you throw it } \\
\text { out, the signal will stop moving, and } \\
\text { they'll know you foud the dot. }\end{array}$ & $\begin{array}{l}\text { Biarkan itu di dalam saku Anda. Jika Anda } \\
\text { membuangnya, mereka tahu Anda telah menemukan } \\
\text { alat itu. }\end{array}$ \\
\hline
\end{tabular}

This conversation happened when Sophie found out that Langdong was being watched by police who placed tracking dot in his pocket. Langdon, disturbed by the tracker, wanted to throw it away. Sophie, knowing the game by the police, stopped him. If he throw the tracker away, the signal stop moving and the police would know him found the tracker. Therefore, in this case, bald on record is applied because doing the FTA is primarily in the hearer's interest, by doing the FTA the speaker conveys that she cares about the hearer so that no redress is required (Brown and Levinson, 1987:98). The translation is in the same form. "Leave it in your pocket.." is translated into, "Biarkan itu di dalam saku Anda" which is also imperative and belongs to bald on record. In other word, there is no shift of politeness strategy in the translation.

\section{Positive Politeness}

There are six utterances applying positive politeness. Positive politeness is redress directly to the adressee's positive face, his perennial desire that his wants should be thought as desirable (Brown and Levinson, 1987:101). One of the examples is a conversation between Aringarosa and Silas. Silas is a faithful follower of Opus Dei who was saved by Aringarosa from a street.

\begin{tabular}{|c|l|c|}
\hline No & \multicolumn{1}{|c|}{ Source Text } & \multicolumn{1}{c|}{ Target Text } \\
\hline 3 & $\begin{array}{l}\text { So, my pupil, tell me what I must } \\
\text { know. }\end{array}$ & Jadi, muridku, ceritakan apa yang harus kutahu. \\
\hline
\end{tabular}

The speaker applies positive politeness by using certain adressee, in this case "my pupil' in order to implicitly claim the common ground with the hearer that is carried by that definition of the group (Brown and Levinson ,1987: 107). By adressing 'my pupil', Aringarosa proposed a close relationship between pupil and teacher. Therefore, he gave a feeling of in-grup solidarity among them.

"So, my pupil, tell me what I must know." is then translated into "Jadi, muridku, ceritakan apa yang harus kutahu." which applies the same politeness strategy. Therefore, 
there is no shift of politeness strategy in the translation. They both apply positive politeness. Another example is given below. A conversation between Fache, a police captain, and Langdon.

\begin{tabular}{|c|l|l|l|}
\hline No & \multicolumn{1}{|c|}{ Source Text } & \multicolumn{1}{|c|}{ Target Text } \\
\hline 16 & $\begin{array}{l}\text { Please come find me directly, Mr. } \\
\text { Langdon. There is more we need to } \\
\text { discuss. }\end{array}$ & $\begin{array}{l}\text { Harap Anda langsung menyusul kesana. Ada } \\
\text { yang masih harus kita diskusikan. }\end{array}$ \\
\hline
\end{tabular}

In this case, Fache, who is a police captain, invited Langdon to his place to discuss something which is seemingly in the interest of Langdon too. It is another way for the speaker, Fache, to communicate to the hearer that share some of his wants to intesify the interest in his own contribution to the conversation by making a 'good story' (Brown and Levinson ,1987: 106).

Fache's utterance, "Please come find me directly, Mr. Langdon. There is more we need to discuss." is translated into "Harap Anda langsung menyusul kesana. Ada yang masih harus kita diskusikan." which applies the same politeness strategy. So, there is no shift of politeness strategy in the translation. They both appliy positive politeness.

\section{Negative Politeness}

Four utterances applying negative politeness were found. Negative politeness is redressive action addressed to the addressee's negative face: his want to have his freedom of action unhindered and his attention unimpede (Brown and Levinson, 1987:101).

\begin{tabular}{|c|l|l|}
\hline No & \multicolumn{1}{|c|}{ Source Text } & \multicolumn{1}{|c|}{ Target Text } \\
\hline 1 & If you would be so kind... could you & Tolonglah Tuan yang baik...tanyakan nama orang \\
& take the man's name and number and \\
teel him I'll try to call him before I live & tersebut dan nomer teleponnya, dan katakan juga \\
& Paris on Tuesday? Thank you. & $\begin{array}{l}\text { sakan menghubunginya sebelum saya } \\
\text { meninggalkan Paris hari Selasa. Terimakasih. }\end{array}$ \\
\hline
\end{tabular}

The example above is a conversation between Langdon and a hotel receptionist. Langdon was just awaken by a ring of phone. He was sleeping in a luxurious hotel and just felt asleep a couple of minutes after an exhausting seminar. Feeling that the receptionist had been disturbing very much, he was asking him to give the name and the number. Langdon's command, of course an unavoidably face threatening act. Therefore, he applied negative politeness to minimize the particular imposition that the face threatening act unavoidable affects (Brown and Levinson, 1987:101).

The utterance, "If you would be so kind... could you take the man's name and number and teel him I'll try to call him before I live Paris on Tuesday? Thank you." is translated into 
"Tolonglah Tuan yang baik...tanyakan nama orang tersebut dan nomer teleponnya, dan katakan juga saya akan menghubunginya sebelum saya meninggalkan Paris hari Selasa. Terimakasih." The two utterances apply the same strategy. Therefore, there is no shift of politeness strategy in the translation. Both the They both the utterances, the source text and the target text apply negative politeness.

Another negative politeness applied in an utterance is a conversation between a police agent and Fache.

\begin{tabular}{|c|c|c|}
\hline No & \multicolumn{1}{|c|}{ Source Text } & \multicolumn{1}{c|}{ Target Text } \\
\hline 20 & I think you better take this call. & Saya rasa lebih baik Anda menerima telepon ini \\
\hline
\end{tabular}

Fache is panicked by the situation. Trying very hard to catch Langdon that stakes his reputation as an experienced captain, he had been in highly depressed. This made everybody around him depressed too. An agent who is, of course, under his authority just got a phone call which is directly intended to Fache. In a very careful manner, he gave the phone to Fache. The agent applied negative politeness because his boss was panicked and giving him imposition would ruin the situation. In this expression, "I think you better..." minimizes the imposition.

The utterance, "I think you better take this call."is translated into "Saya rasa lebih baik Anda menerima telepon ini". They both apply the same strategy; negative politeness. It is concluded that there is no shift of politeness strategy in the translation. Both of them apply negative politeness.

\section{IV.CONCLUSION}

From the description and discussion above, there are some conclusion derived :

1. Only three strategies propossed by Brown and Levinson were apllied in the directive speech act in The Da Vinci Code. They are bald on record, positive politeness and negative politeness

2. The same interlocutors (the speakers and hearers) applied different strategies in different situation, meaning that there is noone single strategy applied to similar interlocutors at all time.

3. All the strategies applied in the source text are transferred exactly the same strategies into the target text. There is no strategy shift. 


\section{REFFERENCES}

Baker, Mona. (1992). In Other Words. London and Newyork: RoutLedge.

Brown and Levinson. (1987). Politeness; Some Universals in Language Usage. United Kingdom: Cambridge University Press.

Catford, J. C. (1980). A Linguistik Theory of Translation. London: Oxford University Press.

Dan Brown. (2003). The Da Vinci Code (Novel). New York: Doubleday. . (2003). The Da Vinci Code (Novel terjemahan). Jakarta: Serambi Ilmu Semesta.

Gazdar, Gerald. (1979). Pragmatics, Implicature, Presupposition, and Logical Form. England: Academic Press.

Hatim, B. and I. Mason. (1997). The Translator as Communicator. London/New York: Routledge.

Larson, Mildred A. (1984). Meaning-Based Translation. Lanham: University Press of America.

Leech, Geoffrey. (1983). Principles of Pragmatics. London: Longman Group Limited.

Newmark, Peter. (1981). A text Book of Translation. Singapore:Prentice Hall.

Nida, Eugene A. (1969). The Theory and Practice of Translation. Den Hag: E.J. Brill. (1996). Context in Translating. Amsterdam: John Benjamins Publishing Co.

Yule, George. (1996). Pragmatics. New York: Oxford University Press.

Farewell dan Heimrich. (2006). Pragmatics and Translation. www.accurapid.com/pragamatics/html. 